\title{
Description of the first-instar larva of Geocharidius (Coleoptera: Carabidae: Trechitae) with a discussion of the phylogeny of the subtribe Anillina
}

\author{
VASILY V. GREBENNIKOV \\ Department of Zoology and Entomology, Faculty of Natural and Agricultural Sciences, University of Pretoria, Pretoria 0002, South \\ Africa; e-mail: vvgrebennikov@zoology.up.ac.za \\ Biodiversity Program, International Centre of Insect Physiology and Ecology, Nairobi, Kenya; e-mail: v_grebennikov@mail.ru
}

Key words. Geocharidius, Anillina, Trechitae, Carabidae, Coleoptera, larva, description, phylogeny

\begin{abstract}
This paper describes the first-instar larva of Geocharidius Jeannel, a species from Mexico, which is the second record of an Anillina (Coleoptera: Carabidae: Trechitae) larva; previously described was a species of the European genus Typhlocharis. Larvae of these two genera share ten synapomorphic characters, which support the monophyletic origin of Anillina. Sister-group relationships of Anillina with Tachyina + Xystosomina are proposed on the basis of three shared larval synapomorphies: seta LA5 of ligula absent; coronal suture in first-instar larvae very short or absent; second- third-instar larvae have none or one secondary seta on lateral sides of stipes and labium and none on mandibles.
\end{abstract}

\section{INTRODUCTION}

The subtribe Anillina includes 43 genera of the smallest carabid beetles (Jeannel, 1963; Cicchino \& RoigJuñent, 2001; Y. Bousquet, personal communication), which are distributed in all zoogeographical regions. Only one description of a larva of an unidentified species of the genus Typhlocharis Dieck, 1869 has been published (Arndt et al., 1999). This larva has seven presumably apomorphic characters previously unknown for the members of the supertribe Trechitae (Maddison, 1993; Grebennikov, 1996, 1997, 1999; Grebennikov \& Bousquet, 1999; Grebennikov \& Luff, 1998, 1999; Grebennikov \& Maddison, 2000; Arndt, 2000). The lack of other Anillina larvae prevented Arndt et al. from reaching a conclusion about the monophyly of the subtribe and its phylogenetic affinities.

During a short visit to the Museum of Comparative Zoology in $1998 \mathrm{I}$ had an opportunity to examine some vials containing unidentified carabid larvae. One of them contained about 20 Anillina adults with a single larva collected by Alfred Newton in Mexico, using Berlese funnels. When I borrowed these specimens and made microscopal preparations it was evident that the adults were indeed Anillina, and apparently those of the genus Geocharidius Jeannel, 1963 revised by Erwin (1982). Based on numerous morphological similarities to the one described by Arndt et al. (1999), I concluded that the larva in the vial was also that of a species belonging to the subtribe Anillina.

The aim of the present work is to describe the morphological characters of this Mexican Anillina larva and compare them with those described by Arndt et al. (1999) for Typhlocharis larvae. This comparison based on the presence of shared synapomorphies between the Mexican larva and those of Typhlocharis makes it possible to revise the previously proposed larval diagnosis of Anillina (Arndt et al., 1999) and to discuss two controversial hypotheses concerning the monophyly of the subtribe (Jeannel, 1937, 1963; Erwin, 1982). Additionally, the relationships of Anillina within the supertribe Trechitae is re-evaluated based on new possible synapomorphies of larvae and a new phylogenetic hypothesis is proposed.

\section{MATERIAL AND METHODS}

One larval specimen of Mexican Anillina has the following label: "Mus. Comparative Zoology, Carabidae (Coleopt.): Anillina, Geocharidius sp., first instar by association with 20 adults; no other Anillina in the sample. MEX: Oaxaca, $17.6 \mathrm{mi}$ S Ixtlán de Juárez 7900' VIII.19.1973 berl., leaf \& log litter, oak woodland. Al. Newton coll. Det. V. Grebennikov". The reason for believing that the larva and adults of Anillina from Mexico are conspecific is that all the Anillina adults originated from the same locality as the larva. All the adults are similar and apparently conspecific. The same reasoning based on adult-larval association was used by the authors of the first larval description of Anillina (Arndt et al., 1999) to identify larvae collected together with Typhlocharis adults.

Adults of Geocharidius in the same sample as the larva were later studied by T.L. Erwin (Smithsonian Institution, Washington DC., U.S.A.). He confirmed that they belong to this genus and were either new, or $G$. integripennis (Bates, 1882). He also commented that "these are the first Geocharidius I have seen from north of the Isthmus of Tehuantepec, therefore can't say if they are conspecific with $G$. integripennis from Guatemala" (T.L. Erwin, personal communication).

The larva was beheaded and the body was cut transversally between 2nd and 3rd abdominal segments. These parts were cleared in a hot water solution of $\mathrm{KOH}$ and mounted on a microscope slide in Euparal. Six adults were mounted in Euparal on the same slide. The remaining adults in the vial were labelled, and all material returned to the Museum of Comparative Zoology, Harvard, Boston, U.S.A. Morphological terms used in this work are those of Lawrence (1991: 147-177). Chaetotaxy is that of Bousquet \& Goulet (1984). Asterisk $\left({ }^{*}\right)$ indicates sensilla with questionable homology. The format of the description of the larva of Geocharidius is comparable to that of the previously described larva of Typhlocharis. The characters shared by the 


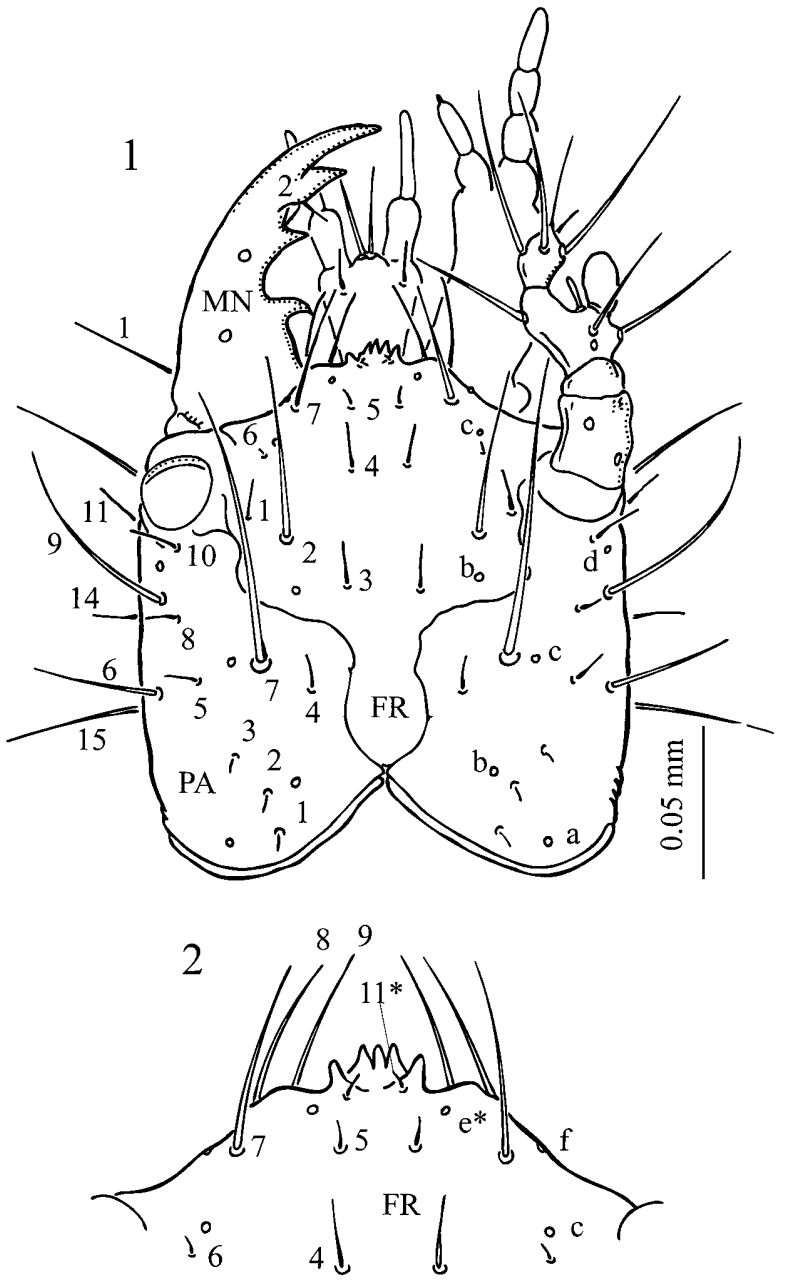

Figs 1-2. First-instar larva of Geocharidius sp., dorsal view. 1 - head (left antenna, right mandible and left maxilla removed); 2 - anterior part of frontale (= nasale).

larvae of these two genera are listed under description of Anillina larvae. The unique characters of Anillina are used in the diagnosis of the group within the supertribe Trechitae. Characters are numbered with Roman and Arabic numerals respectively, the Arabic ones corresponding to those in Grebennikov \& Maddison (2000).

Plesiomorphic morphological characters in larval Trechitae were identified using the supertribe Patrobitae as an outgroup. This is based on the hypothesis that Patrobitae and Trechitae form a well-defined monophyletic group (Maddison et al. 1999). Larvae of about 30 Trechitae and four Patrobitae genera were compared; those of Trechitae are listed in Grebennikov \& Maddison (2000) and those of Patrobitae in Bousquet \& Grebennikov (1999).

The single first-instar larva of Geocharidius differs from older-instar (second- or third-) larvae of Typhlocharis in many respects. Some are expected differences between larvae of different taxa and between first- and older-instar Trechitae larvae. For comparison I hypothesised how Typhlocharis larvae might appear in the first instar and then compared these hypothetica attributes with those of Geocharidius. The opposite hypothesis that of the older larva of Geocharidius seems less justified because older larvae of Trechitae have a more complex morphology than first instar larvae. As this opposite would have required a larger number of assumptions it was rejected. How- ever, in the larval description of Anillina I use characters of older instars based on those of Typhlocharis.

\section{RESULTS}

\section{Subtribe Anillina}

\section{Diagnosis}

Larvae of the subtribe Anillina might be distinguished from those of the majority of other Trechitae taxa by their exceptionally minute size (head width of mature larvae expected to range from about 0.160 to $0.250-0.300 \mathrm{~mm}$ ). Additionally, Anillina larvae are unique within the subertribe in possessing the following mandibular characters: two large and peculiar teeth present on terebra in addition to retinaculum, seta MD2 relatively long, and penicillus absent.

\section{Description}

General appearance and characters. Minute larvae with normal appearance of those of Trechitae. All primary setae and pores present if not mentioned otherwise.

Cephalic capsule (Fig. 1). Parallel-sided and slightly elongated. Maximal width ranges from $0.160-0.180 \mathrm{~mm}$ in older-instar Typhlocharis larvae and $0.164 \mathrm{~mm}$ in Geocharidius larva. Frontale U-shaped at base; reaching posterior margin of cephalic capsule; coronal suture (= epicranial stem) absent. Stemmata and ocular groove absent; cervical groove markedly reduced (Typhlocharis) or absent (Geocharidius). Egg-bursters in first-instar absent. Nasale serrate (Fig. 2) (Geocharidius) or rounded apically (Typhlocharis). Hypopharynx and stipes with relatively long anteriorly directed setae. Chaetotaxy. Pore FRa absent; seta PA5 absent (Typhlocharis) or present (Geocharidius); seta in anterior angles of epipharynx not found (possibly due to small size of larvae).

Antenna. Antennal fossa separated from pleurostoma by relatively wide strip of sclerotized cuticle. Antennomere 2 markedly reduced in length (Geocharidius) or absent (Typhlocharis). Proximal antennomere with only two pores.

Mandible. With relatively wide base; penicillus lacking; retinaculum comparatively small; terebrum, apical of retinaculum, with two teeth of size about equal to that of retinaculum; terebrum without dorsal carina; dorsal surface of mandible without microsculpture. Seta MD2 markedly longer than in remaining Trechitae larvae. Older instar larvae without secondary setae.

Ventral mouthparts. Maxilla without lacinia; with comparatively wide stipes. Stipes without teeth at base; with not less than 10 seta on gMX in first instar (2-3 or more setae might be overlooked due to small size of larva); without secondary setae in older instars. Labium with short ligula; apical palpomere relatively long; setae LA4 and LA5 absent; without secondary setae in older instars.

Thorax. Pores PRc, PRe, PRi and PRj absent; pores $\mathrm{PRh}$ and PRf not found (possible due to small size of the larva). Sensilla EM1 on prothorax, EM1 and ES1 on mesothorax and EM1 on metathorax present as short tri- 
choid setae. Legs with single claw and without microspines on coxa in first-instar. Setae TA3, TA4, TA5 and TA6 absent; seta TA1 located on basal fifth of tarsus; single claw seta as long as claw diameter at base.

Abdomen and urogomphi. Pore TEb absent. Sensillum EP1 on ninth segment present as short trichoid seta.

Spiracles. Annular spiracles present on mesothorax and abdominal segments I-VIII.

\section{Genus Geocharidius Jeannel, 1963}

Diagnosis and description. Larvae of the genus Geocharidius differ from those of the genus Typhlocharis in the following characters: (a) antennomere 2 present and markedly reduced in length; (b) nasale with serration; (c) nasale not rounded apically; (d) seta PA5 present; (e) seta FR6 moved mediad instead of being located at lateral margin of frontale. Sensilla FR10 and FRd on frontale not found.

\section{DISCUSSION}

\section{Larva of Geocharidius}

The only known first-instar larva of the genus Geocharidius appears relatively less morphologically derived than older-instar larvae of Typhlocharis. Four of the five morphological differences between larvae of these two genera (a-d) appear to be apomorphies for Typhlocharis and plesiomorphies for Geocharidius.

\section{Previously proposed phylogenetic affinities of Anillina}

There are two hypotheses regarding the phylogenetic relationships of Anillina. Jeannel (1937, 1963) thought that the group is monophyletic with Lymnastina the sister-group. Erwin (1982) considered Anillina as a grade derived from Paratachys Casey, 1918 and allies, each of which adapted independently to a deep-humus environment. Larvae of Lymnastina are unknown, therefore it is not possible to discuss Jeannel's proposal. In support of Erwin's hypothesis, there is an indication that Anillina might be related to Paratachys (see section "Paratachys as possible close relative of Anillina ").

\section{Monophyly of Anillina (Geocharidius and Typhlocharis)}

Currently, with larvae of only two of about 43 Anillina genera, Erwin's hypothesis (1982) of a non-monophyletic origin of Anillina can be neither seriously disputed nor corroborated. However, the present study of Geocharidius larvae and their comparison with those of Typhlocharis yielded 10 morphological characters, which might be considered as possible larval synapomorphies for Anillina. They are unique for larvae of Trechitae and are: (i) mandibular terebra with two relatively large peculiar teeth; (ii.) relatively long seta MD2 on mandibles; (iii) penicillus absent; (iv) basal antennomere with only two pores; (v) antennomere 2 completely lacking (Typhlocharis) or markedly reduced in length (Geocharidius); (vi) labium with seta LA4 absent; (vii) pore FRa on frontale absent; (viii) antennal fossa separated from pleurostoma by a wide strip of sclerotized cuticle; (ix) hypopharynx and stipes with relatively long anteriorly directed setae; $(x)$ retinaculum relatively small. Because four of these characters (i-iii, $\mathrm{x}$ ) are associated with mandibles, they might be also regarded as a complex coadapted change of a single structure.

\section{Phylogenetic affinities of Anillina within Carabidae}

Judging by the larval morphology, there is little doubt that the subtribe Anillina belongs to the supertribe Trechitae. The monophyly of the supertribe is supported by the following synapomorphic characters, all of which are present in Anillina larvae, i.e. absence of pores PRc, PRe, PRi, PRj on prothorax, pores MEd and MEe on mesoand metathorax, pore TEb on abdominal terga I-VIII and setae TA3, TA4, TA5 ad TA6 on tarsus (Arndt et al., 1999; Grebennikov \& Maddison, 2000).

\section{Possible sister-group relationships of Anillina and Tachyina + Xystosomina}

The recently published revision of larvae of Tachyina and Xystosomina (Grebennikov \& Maddison, 2000) yielded 10 presumable larval synapomorphies for these two groups. Two of them (numeration follows Grebennikov \& Maddison, 2000) are shared by larvae of Anillina. They are: (06) seta LA5 on ligula is absent and (08) coronal suture in fi rst instar larvae is very short or absent. Additionally, larvae of Anillina might exhibit a more advanced stage of the synapomorphic character 10 of Tachyina and Xystosomina, namely: second- and thirdinstar larvae with only one secondary seta on lateral sides of stipes and labium, and mandibles without secondary setae. In Anillina larvae (condition is known only for Typhlocharis) there are no additional setae on mouthparts in older instars. The synapomorphic character 05 (seta FR6 on frontale more mediad instead of being located near lateral margin of frontale) is known in Anillina in both plesiomorphic (Typhlocharis) and apomorphic (Geocharidius) conditions and, therefore, is not informative.

The remaining five larval synapomorphies of Tachyina + Xystosomina are absent in Anillina larvae and therefore provide support for Tachyina + Xystosomina as a welldefined clade. (01) Presence of six long setae on urogomphi in second and third instars (Typhlocharis larvae have seven setae). (02) Group gMX consists of no more that six (usually five) setae (first-instar Geocharidius larva has not less than 10-11 setae; additionally about 2-3 setae might be overlooked due to small size of the larva). (03) First-instar larvae with sensilla EM1 on prothorax, EM1 and ES1 on mesothorax, EM1 on metathorax and EP1 on IX abdominal segment modified as pore-like structures, instead of being trichoid setae (firstinstar Geocharidius larva has all these sensilla as trichoid setae). (04) Second and third-instar larvae with 1-7 (usually 4-6) secondary pore-like structures on anterior ventrites of meso-, metathorax, and all abdominal segments (no such structures are noted for Typhlocharis larvae). (07) Stipes with one or more teeth at base (known Anillina larvae have no teeth at base of stipes). (09) Firstinstar larvae with some microspines on dorsal surface of 
coxa, instead of being smooth (no microspines are noted for Geocharidius larvae).

Consequently, two larval synapomorphies of Tachyina + Xystosomina (06 and 08) are shared by those of Anillina. One character (05) occurs in Anillina in both apomorphic and plesiomorphic forms. Condition of one more synapomorphic character of larval Tachyina (state of character 10 is unknown for Xystosomina) might be regarded as more advanced apomorphy for Anillina. However, there are six presumable synapomorphies of Tachyina and Xystosomina $(01,02,03,04,07,09)$ not found in Anillina larvae.

Thus the following tentative phylogenetic hypothesis might be proposed: Tachyina and Xystosomina form a clade supported by six synapomorphies (characters 01, 02, 03, 04, 07, 09 in Grebennikov \& Maddison, 2000). The genera Geocharidius and Typhlocharis also form a clade supported by ten larval synapomorphies discussed under the section "Monophyly of Anillina". Based on three larval synapomorphies (characters 06, 08, 10 in Grebennikov \& Maddison, 2000) these two clades are sister-groups.

\section{Paratachys as possible close relative of Anillina}

Erwin (1982) supposed that Anillina might be derived from Paratachys and its allies. The present larval study provides one indication that Anillina might indeed be derived from Paratachys. Two peculiar teeth on terebra in Anillina might be regarded as a more advanced stage of the apparently apomorphic mandibular serration in Paratachys larvae (Grebennikov \& Maddison, 2000: 238). However, this character provides weak evidence of an Anillina origin from Paratachys since similar serration occurs in larvae of three of eight genera of Tachyina and Xystosomina (Grebennikov \& Maddison, 2000). Moreover, the independent origin of the mandibular serration within Trechitae was also noted for larvae of the genera Thalassophilus Wollaston, 1854 and Perileptus Schaum, 1860 (see Grebennikov, 1996; Grebennikov \& Luff, 1999). Consequently, there are doubts whether mandibular teeth in Anillina and mandibular serration in Paratachys are indeed homologous. Additionally, the assumption of an Anillina origin from Paratachys depends on the assumption that all six presumed larval synapomorphies of Tachyina + Xystosomina, which are not found in Anillina (01, 02, 03, 04, 07, 09) are a reversal of the characters in the last group.

\section{CONCLUDING REMARKS}

The present discovery of the Geocharidius larva in Mexico is only the second larva of about 43 genera of Anillina to be described and, therefore, all preliminary conclusions have to be eventually corroborated when larvae of more taxa are known. Currently there are ten larval synapomorphies supporting the monophyletic origin of Anillina and this number is expected to decline when more Anillina larvae are described. Three other synapomorphies clearly indicate close relationships of Geocharidius + Typhlocharis with Tachyina + Xystosomina; the monophyly of the last two subtribes is sup- ported by six more larval synapomorphies. Like in the previous study (Grebennikov \& Maddison, 2000: 239), no synapomorphic feature was discovered for a sistergroup to Anillina + (Tachyina + Xystosomina) within the supertribe Trechitae in general and the subtribe Bembidiina in particular. Erwin's (1982) hypothesis of an Anillina origin from Paratachys cannot be dismissed since there is at least one larval attribute supporting it, namely the presence of presumably homologous mandibular serration or teeth in larvae of both groups. The basis of Erwin's hypothesis is the adult synapomorphy of a secondary protibial cleaning devise found only in the "higher Tachyina", not in Xystosomina. Hence, if Anillina are indeed monophyletic, the protibial cleaning devise in adults is a convergent character.

ACKNOWLEDGEMENTS. Philip D. Perkins (Harvard University, U.S.A.) allowed me to work on the collection of the Museum of Comparative Zoology and to borrow the unique Geocharidius larva. Collecting efforts of Alfred F. Newton (Field Museum, Chicago, USA) made this study possible. Terry L. Erwin (Smithsonian Institution, Washington DC, U.S.A.) confirmed the generic identification of the Geocharidius adults, proposed possible species names for them, and critically read the MS before submission. Yves Bousquet (Eastern Cereal and Oilseed Research Centre, Ottawa, Canada) shared his unpublished information from the catalogue of the Anillina genera.

\section{REFERENCES}

ARNDT E. 2000: Larvae of the subfamily Trechinae from the Southern Hemisphere (Insecta: Coleoptera: Carabidae). Spixiana 23: 85-91.

Arndt E., GrebenniKov V.V. \& Zaballos J.M.P. 1999: Description of the larvae of a representative of Anillina with a key to the Palaearctic genera of Bembidiini (Coleoptera: Carabidae). Koleopt. Rdsch. 69: 11-17.

Bousquet Y. \& Goulet H. 1984: Notation of primary setae and pores on larvae of Carabidae (Coleoptera: Adephaga). Can. J. Zool. 62: 573-588.

Bousquet Y. \& GreBenNiKov V.V. 1999: Platypatrobus lacustris Darlington (Coleoptera: Carabidae): adult and larval morphology. Fabreries 24: 1-13.

Cicchino A.C. \& RoIG-JuÑent S. 2001: Description and relationships of Paranillopsis new genus, two new species from Argentina, and a key to the Neotropical genera of the subtribe Anillina (Coleoptera: Carabidae: Bembidiini). Coleopt. Bull. 55: 185-193.

ERWIN T.L. 1982: Small terrestrial ground beetles of Central America (Carabidae: Bembidiina and Anillina). Proceedings of the California Academy of Sciences 42: 455-496.

GreBennikov V.V. 1996: Description of the first instar larva of Thalassophilus longicornis (Coleoptera: Carabidae: Trechodina). Acta Soc. Zool. Bohem. 60: 373-379.

GreBennikov V.V. 1997: Larvae of Bembidiini: subgenera Synechostictus and Pseudolimnaeum of the genus Bembidion and their taxonomic position (Coleoptera: Carabidae). Zoosystematica Rossica 5 (1996): 263-272.

Grebenntrov V.V. 1999: Larvae of Zolini (Coleoptera: Carabidae): genera Oopterus Guérin-Ménéville and Idacarabus Lea. Coleopt. Bull. 53: 245-252.

Grebennikov V.V. \& Bousquet Y. 1999: Larvae of Pogonini (Coleoptera: Carabidae): genera Pogonus, Pogonistes, Cardiaderus, and Thalassotrechus. Acta Soc. Zool. Bohem. 63: 427-441. 
GrebenNIKov V.V. \& LuFf M.L. 1998: Description of larvae of Aepopsis robini (Coleoptera: Carabidae: Trechini). Eur. J. Entomol. 95: 623-627.

GrebenNiKov V.V. \& LufF M.L. 1999: Morphological study of Perileptus larvae (Coleoptera: Carabidae: Trechitae). In Zamotajlov A.S. \& Sciaky R. (eds): Advances in Carabidology. Papers dedicated to the memory of Dr. Prof. O.L. Kryzhanovskij. MUISO Publishers, Krasnodar, pp. 153-164.

GREBENNIKOV V.V. \& MADDISON D.R. 2000: Larvae of Bembidiini (Coleoptera: Carabidae): subtribes Tachyina and Xystosomina. Eur. J. Entomol. 97: 223-240.

JEANNEL R. 1937: Les bembidiides endogés (Coleoptera: Carabidae). Monographie d'une lignée gondwanienne. Revue Fr. Entomol. 3: 341-399.
JEANNEL R. 1963: Monographie des “Anillini”, Bembidiides endogés (Coleoptera: Trechidae). Mem. Mus. Natn. His. Natur., Série A. Zoologia 28: 33-204.

LAWRENCE J.F. 1991: Order Coleoptera (general discussion, family key, various family treatments). In: Stehr F.W. (ed.): Immature Insects, Vol. 2. Kendall/Hunt Publishing Co., Dubuque, Iowa, pp. 144-658.

MADDISON D.R. 1993: Systematics of the Holarctic subgenus Bracteon and related Bembidion (Coleoptera: Carabidae). Bull. Mus. Comp. Zool. 153: 143-299.

Maddison D.R., BaKer M.D. \& Ober K.A. 1999: Phylogeny of carabid beetles as inferred from $18 \mathrm{~S}$ ribosomal DNA (Coleoptera: Carabidae). System. Entomol. 24: 103-138.

Received September 14, 2001; revised March 6, 2002; accepted April 26, 2002 